\title{
On the Issues of Agricultural Industry Fund to Support the Family Farm
}

\author{
W. Z. MIN \&Y. Z.YING \\ Hebei University of Engineering, College of Arts, Handan City, Hebei Province, China
}

Z. XIN

Communication University of China, Beijing, China

\begin{abstract}
In recent years, China's local governments take to support the development of family farms as the important work of the local agricultural modernization. They published a number of financial policy to support agricultural development. Built agricultural industry fund is the one of those. Compared with other measures, it has a unique advantage that can combined guiding with support to pull the promotion of family farm. But lot of local governments has not realized the role of agricultural industry funds in the development of family farms.
\end{abstract}

KEYWORD: agricultural modernization; the family farm; finance; support policy; industry fund

The concept of family farm is first proposed at the third plenum of the $17^{\text {th }}$ communist Party of China central committee. It is said that some "places can develop professional investors, family farms, farmers cooperatives and other scale operation organization." Since then, the family farm is regarded as one of the important carriers of the agricultural production of our country to take the intensive, large-scale and modernization. In 2013, Ministry of Agriculture for the first time carried out the statistical investigation on the national family farm development. The Investigation showed that, by the end of 2012, the number of the family farm which complies with the requirements for survey was 877000 . It showed the overall scale of family farm groups was large. The file also proved that family farm is very obvious in increasing income compared with the traditional farmers. Since 2013, government began to focus on the plan of development path and direction of the family farm. The No1. policy document of 2013 from the central government firstly adopted the "family farm" conception. It was to put forward: To encourage and support the land transfer to professional investors, family farms, farmers cooperatives. The No1. policy document of 2014 from the central government once again put forward to support the development of new agricultural management Organization including the family farm. On February 24th of 2014, Ministry of Agriculture issued the "opinions on promoting the development of family farms". It put forward guiding opinion in ten aspects, such as the important meaning to promote the development of family farms, grasp the basic characteristics of the family farm, and guide the requirements, improve service system, the relevant supporting policies, family farm coalition and cooperation etc.

Thus, the family farms have become an important measure of the Chinese government to promote the development of agriculture.

As we all know, the family farm development is inseparable from the two important conditions, land and capital. In recent years, along with the implementation of national and local land circulation policy, land concentrated more and more easily, the size of family farm expanded rapidly. At the same time, more and more research shows that the family farm financing problem has not yet been effectively alleviated. It has become a major obstacle that restricts the development of family farms. In August 2014, the Ministry of Agriculture issued a notice: "On promoting modern agricultural development with financial support and service" (hereinafter referred to as the "notice"). It points out that our agriculture has entered a high investment, high costs of development stage with the agricultural scale, 
standardization, organization, intensive level continues to improve, and advanced science and technology and agricultural equipment application rapid popularization. The rural economy demand for financial support and services become more and more vigorous. The degree of dependence significantly enhanced. However, Li Jianhua who works in the financial department of the Ministry of Agriculture Secretary, in accepting the "farmer daily" interview, said that "loans" is a serious problem that some new agricultural management subject is facing. On the one hand, agricultural development needs a large number of loans; on the other hand, there are many barriers to prevent farms from receiving loans by the common channel.

Compared with industrial, agriculture is more difficultly to obtain the support of commercial loans because of the characteristics, such as large investment, long period, affected deeply by the weather, low income. Meanwhile, compared with other agricultural entities, the legal status of family farms is unidentified, lack of traditional collateral. Even if allowed to land contractual management rights and other as collateral material, its valuation and circulation is still difficult. Li Jianhua, Financial Secretary in the Ministry of Agriculture, also pointed out: "At present, the peasant's microfinance system is relatively perfect, the financing channels of agricultural industry guiding enterprises is relatively smooth, the most prominent problem is now relatively fast development of new agricultural business entities 1." In order to solve this problem, In April 2014, the general office of the State Council issued" Certain opinions on the financial service for the "three rural" development". It is pointed out that "rural finance is still is the most weak link in the entire financial system", and put forward nine measures. "Notice" also pointed out the current rural finance channel between supply and demand is still sluggish, the needs of rural financial and rural economic development has not been effectively met, it has become one of the most prominent of rural financial, and one of the most important factors of restricting development of modern agriculture". And it has made deployment to push all the agricultural sectors to promote financial support for agriculture. Clearly, the problem of financing has become the most important factor restricting the development of family farms.

From the development history of developed countries in modern agricultural, agricultural industry fund often play an important role in easing the financing problem. "Notice" also rose that the fiscal and financial policy support for agriculture has synergistic effect. At present, China's local

1. Xibao,S.2014. It is difficult to meet the huge demand for funds bringing by large-scale production with financial subsidies, the "Loan difficult" problems of new agricultural operators are highlighted[N].worker's daily,2014-08-13 government investment in agriculture is mainly through direct financial subsidies, the government and the bank cooperation loans based on policy, agricultural insurance etc.. But industry investment fund supported by government does not pay due attention to agricultural. The development of agriculture industry fund in China' is relatively slow.

Here talking about is not the usual sense of the industrial fund, but the government guiding fund. It is organized by Government and private that is an important policy that many countries adopted to guide, support the development of the industry. Unlike other government investment, guiding fund is an innovative way. At first, Government establishes a guiding fund, and then supports the investment object which is selected by the guiding funds. In this way, it is not only to leverage more social capital investment in related industries, but also to improve the quality and efficiency of government investment by the way of experienced industry investors to help the government selected projects, investment projects and project management. In 2001, Zhongguancun guiding fund was established as one of pioneer. Then one after another local governments established the guiding funds. But most of them pay close attention to the high-tech enterprises, to agriculture is not much. Only the national guiding funds, such as the Modern Seed Industry Development Fund, China's Agricultural Industry Development Fund etc. put into the field of agricultural. Local government is little interested in establishing the agricultural guiding fund.

Compared with the traditional financing channels, agricultural industry fund is not only beneficial to reform the agricultural investment and financing system, open up new financing channels, but also has advantages in the following aspects:

First, it helps to improve the investment efficiency, while weakening the commercial investment. Direct financial subsidies is unfavorable in the supervision, lower investment efficiency, easy to be diverted from etc.. In addition, along with the international competition and economic integration of the world intensifies, government directly on the agricultural investment is more and more criticized. It has been difficult to make up for the shortfall funds for agricultural development. Although it can improve the efficiency in the investment which is the emerging mode such as cooperation loans form the government and the bank based on policy, the agricultural insurance etc. But it is easily affected by commercial behaviors. In the situations of unidentified legal status of family farms, lack of traditional collateral etc., they cannot be effective to alleviate the problem of financing, and reflect the financial support from government in the development of family farm. Government is actively exploring new ways of financial support form government in the development of agricultural. The 
issue that government and other commercial subject cooperate to establish agricultural industry fund in agriculture investment is not only helpful to improve the efficiency of investment by the intervention of business investor ,but also can restrict commercial in some extent by the way of which government have a greater power in the project selection.

Second, it is in accordance with the present situation of the development of family farms in China and can helps to promote the Large scale production of family farm, and provides comprehensive service. It is requested that investors have a more in-depth understanding of the agricultural policy because agricultural investment and national agricultural policy is closely related to. At the same time, the agricultural investments also need a High-level professional operation and management. However, there are many problems in the development of family farm in the situations, which such as the quality of marketing manager overall is not high; the ability to competitiveness is not strong; the system of government services and guide mechanism is defective, and so on. Although, the number and size of family farms in China has developed rapidly. But the ability of management family farm, the quality of workers cannot also improve. The internal management of the majority of the family farm is quit extensive2. At the same time, the government guidance and service system has not perfect. It leads to that family farms generally are weak in anti-risk ability, competitiveness. The agricultural industry fund managers usually have rich experience in agricultural industry management. They can provide more guidance and training and make up the gap of professional service. That is, industry investment fund can bring not only money, but also professional services etc., while other measures providing often one-sided support, services or money.

Third, it can help to attract more social capital into agriculture. In recent years, with the development of economy in China, it has accumulated amazing amount of wealth in folk. Private capital is increasing enthusiasm for investment. More and more private capital jump into the field of industrial investment. Due to the lack of effective guidance, illegal fund-raising cases are frequent. Agricultural investment cannot draw the attention of private capital. It would solve this problem effectively by the operation of the guiding fund. The guiding fund enter into the agricultural investment field through equity participation, follow-up investment and financing guarantee etc., and then chose the project with the development

2 .Research group of strategic planning department of Agricultural Bank of China.2013.Investigation and Thinking on financial services of family farm [J]. Rural Finance Research, 2013 (12). plan of government. This would effectively improve the income from agricultural investment, while reduce the investment risk. Government credit would enhance to draw more the credit funds, private capital into the investment of agricultural industry and related business.

Because of the above advantages of Agricultural industry fund, it is taken as the primary development measures. "Notice" also pointed out:" Agricultural departments shall actively coordinate with the financial sector, adjust and optimize the fiscal subsidy way, innovative the system of supporting agriculture, give full play to the guiding role of fiscal funds and leverage more financial capital, and strive the two wheel drive which are the fiscal and financial supporting policy ."And it further recommends that local government: "can promote the special fund for agricultural investment." Although the agricultural industry fund established by government has the above advantages, it is difficult to fully play its unique role if it is not designed well. At present, the following aspects should be pay attention to:

First, guiding as the Basics, income is the supplementary. Compared with ordinary commercial investment funds, agricultural industry funds have a unique advantage. It is supported by the power of government. If it is not restricted, financing order would be destroyed. Enthusiasm of commercial investors would be frustrated. The guiding role of agricultural industry fund would not fully play out. Government should not struggle people. The funds established by government should not take its main function on profit but on guiding. It's goal should be to attract more social capital to invest related industries. Of course, agricultural industry funds should also consider profit for the shareholder of private capital. We just oppose to the conducts that completely ignore the guiding practice. If that, government capital would be taken by commercial capital, lost its meaning of existence.

Second, the right of management of agricultural industry funds should be controlled by professional risk management. Government should be supervision, generally do not directly involved in project selection and management. In the specific investment project selection and management, government should not interfere too much. We should trust and rely on the professional management mechanism, give full place to them. Agricultural investment and management is the field of strong occupation and professional activity. It needs to have the professional personnel to carry out. However, to ensure that funds are not fully commercialized, government must retain enough power in the fund supervision. So government in an investment fund shall be a major shareholder to ensure that it has the full right to speak in the 
investment fund operation. To do this, we must carry on the good design of the fund management 3 .

Third, the object which supported by the agricultural industry fund should be the mediumsized family farms. According to the capital source, investment in the area of agricultural industries includes government financial input, farmer's (including both individual and collective) capital input, agricultural credit and other agricultural investment into agriculture. From the relevant research, the small farmers and small family farms required a limited amount. It is enough to meet their capital needs of production with financial subsidies, self and mutual aid and cooperation helps channels etc.; while the family farms, which have become large scale, standardized production, often have a strong asset. They seldom fall to the condition of no collateral. And most of them have been incorporated into the local credit system. With government repeatedly increasing support for agriculture, their credit request is most satisfied. The medium-sized family farms are rapidly growing. Their capital needs of production are not less than large-scale farms. But they often cannot provide mortgage property. Their weaknesses in standardization, scale, anti-risk ability, competitiveness etc. prevent them from commercial financial services. Therefore, mediumsized family farms are difficult to get enough money from the existing financing channels. Agricultural industry funds should be to meet this part of financing demand as its mission. From the two aspects, which are the professional management and financial assistance, it should improve their anti-risk ability, competitive, and then promote large-scale, standardized production as early as possible.

In summary, through establishing investment fund, government can combine the measures of policy oriented and market operation. It is an innovation mechanism of financial support for agriculture. It not only makes up for the blank of current agricultural financial investment, but also helps to play to the faction of financial capital. That will attract more social capital to invest in the agricultural areas. In order to better promote the transformation of agricultural modernization, local governments should set up the agricultural industry fund as early as possible.

\section{REFERENCES}

[1]Chaomin, L.2006.20th century the US farm evolution and policy trajectory to support farm management system. World Agriculture,2006,(2).

3 Zhi-min,W\&Zhi-ying,Y.\&Yan-hua,X.2012.On Improving the internal System of local governmental Leading Fund [J].Sub National Fiscal Research, 2012(11).
[2]Wei, G. 2014.The Development of Family Farm: Problems and Solutions. Journal of Shenyang Agricultural University (Social Sciences Edition), 2014-03, 16(2)

[3]Qibin, G. \& Yao, W. \& Cuiling, G.2011.The diversification of sources of funds of agricultural modernization in China. Productivity Research,2011,(11)

[4]Huichun, H. 2012. China's reform route choice in rural financial market -- Based on the comprehensive perspective of the "body" and "function". Reform of Economic System,2012,(5). 